\title{
Adsorption of IgG to fluoride-treated hydroxyapatite
}

\author{
Kazuhiko Sasaki, Toshio Mori, Masamichi Terashita, \\ Miyota Nagano and Choji Uchiyama* \\ Department of Operative Dentistry (Chief: Prof. Miyota Nagano), \\ *Department of Oral Bacteriology (Chief: Prof. Choji Uchiyama), \\ Kyushu Dental College, Kokura, Kitakyushu 803, Japan
}

[Accepted for publication: September 11, 1984]

Key words: IgG / protein adsorption / hydroxyapatite / fluoride

\section{Introduction}

Immunoglobulin in saliva and crevicular fluid play an important role for protection against caries ${ }^{1)}$. Rölla reported that immunoglobulins, IgA and IgG, constitute a part of the pellicle on the tooth surface ${ }^{2}$. IgG, as well as IgA, may be influenced qualitatively in the development of the dental plaque on the surface of enamel, affecting colonization of Strep. mutans, especially by opsonization ${ }^{3)}$.

On the other hand, topical application of fluorides to teeth is used extensively to reduce dental caries. Eggen et al. observed that the adsorption of albumin to fluoride-treated hydroxyapatite was reduced ${ }^{4)}$.

Thus, fluoride in enamel may increase or decrease the adsorption of specific salivary constitutes. The aim of the present study was to investigate the adsorption of IgG to hydroxyapatite that is treated with $\mathrm{NaF}$, and to compare the adsorption of albumin.

\section{Materials and Methods}

Samples of $100 \mathrm{mg}$ hydroxyapatite (Nihon Chemical Co., Ltd., Japan) were treated with $5 \mathrm{ml}$ of $0.1,1,10$ or $100 \mathrm{mM} \mathrm{NaF}$. The sample was stirred for $1 \mathrm{~min}$, allowed to stand for $10 \mathrm{~min}$ and centrifuged at $3000 \times \mathrm{g}$ for $10 \mathrm{~min}$. The sediment was washed with $5 \mathrm{ml}$ of $1 \mathrm{mM}$ phosphate buffer $(\mathrm{pH}$ 6.8 ) and then the washings were decanted after centrifugation. Untreated hydroxyapatite was used for control.
The procedure for protein adsorption was carried out by a modification of the method of Rölla ${ }^{5)}$. Human IgG (Cappel Laboratories Inc., PA., USA) and Bovine serum albumin (Cappel Laboratories Inc., PA., USA) were dissolved in $1 \mathrm{mM}$ phosphate buffer to yield the following concentration: $1.0,0.5$ and $0.25 \mathrm{mg} / \mathrm{ml}$. To each protein sample $(5 \mathrm{ml})$ was added the fluoride treated hydroxyapatite. The samples were stirred for $30 \mathrm{sec}$, allowed to stand for $10 \mathrm{~min}$, centrifuged at $3000 \times \mathrm{g}$ for $10 \mathrm{~min}$ and then washed with $1 \mathrm{mM}$ phosphate buffer. Desorption of $\mathrm{IgG}$ and albumin was performed by $0.4 \mathrm{M}$ phosphate buffer ( $\mathrm{pH}$ 6.8). The concentration of the protein in the supernatant was measured by the method of Bradford $^{6)}$.

Fluoroapatite was differenciated from calcium fluoride and other forms of labial fluoride by the use of the method of Caslavska et al. ${ }^{7)}$ The fluoride-treated hydroxyapatite $(100 \mathrm{mg})$ was stirred with $1 \mathrm{M} \mathrm{KOH}$ solution $(100 \mathrm{ml})$ for 24 hours. After centrifugation, the supernatant was neutralized with HCl. The concentration of fluoride in the supernatant was done by a fluoride ion electrode (Toa Electronics Co., Ltd., Japan). The KOH-treated hydroxyapatite was washed with distilled water, dissolved in $6 \mathrm{~N}$ $\mathrm{HCl}$, neutralized and then estimated for fluoride content.

\section{Results}

The results showed that the fluoride containing phage formed on the hydroxyapatite 


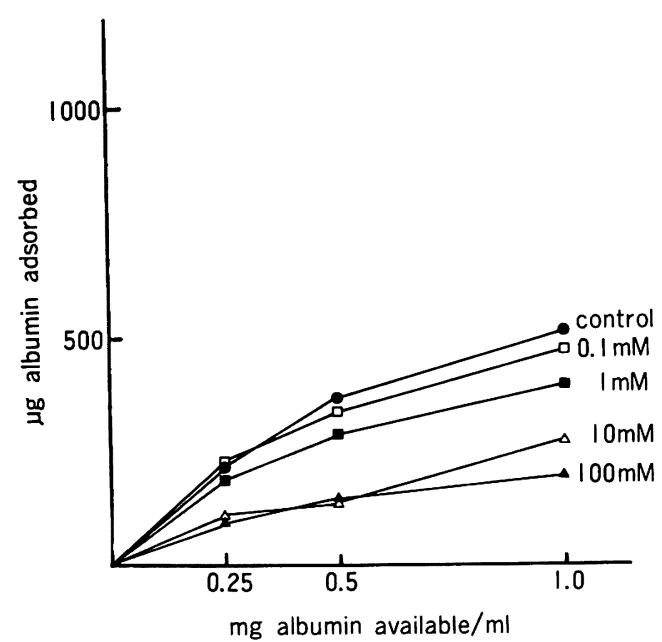

Fig. 1 Adsorption of albumin to hydroxyapatite $(100 \mathrm{mg})$ treated with $0.1,1,10$ or $100 \mathrm{mM} \mathrm{NaF}$.

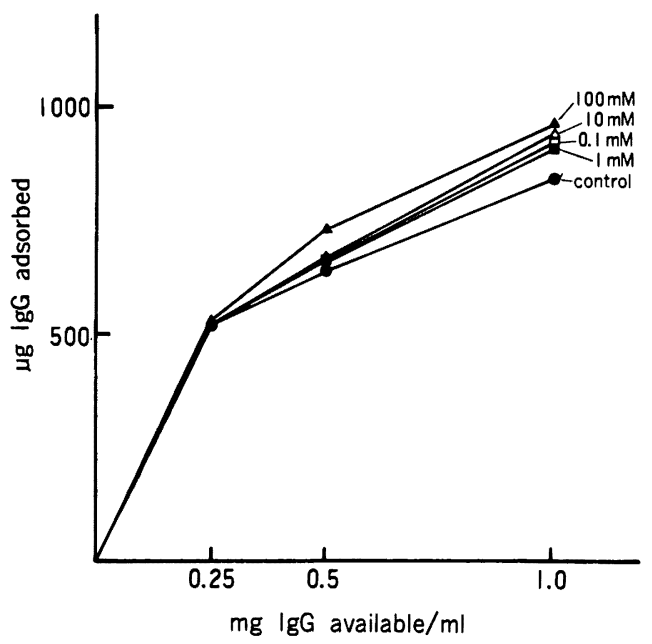

Fig. 2 Adsorption of IgG to hydroxyapatite (100 mg) treated with $0.1,1,10$ or $100 \mathrm{mM} \mathrm{NaF}$.

have an influence on protein adsorption. The treatment of hydroxyapatite with fluoride caused a reduction in adsorption of albumin (Fig. 1). The adsorption of albumin decreased with an increase in the concentration of $\mathrm{NaF}$.

On the other hand, IgG reacted in an opposite way; treatment of hydroxyapatite with fluoride caused a slight increase in the

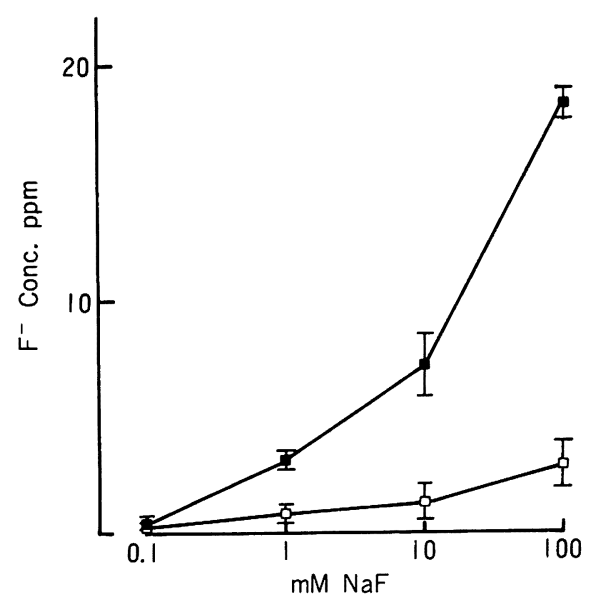

Fig. 3 Fluoride concentrations of NaFtreated hydroxyapatite by $1 \mathrm{M} \mathrm{KOH}$ treatment ( $)$ and subsequent $6 \mathrm{~N}$ $\mathrm{HCl}$ treatment $(\square)$.

adsorption of IgG (Fig. 2). The concentration of $\mathrm{NaF}$ had little effect on IgG adsorpiton.

Incubation of fluoride-treated hydroxyapatite with $1 \mathrm{M} \mathrm{KOH}$ caused the release of the bulk of deposited fluoride (Fig. 3). After treatment of the hydroxyapatite with $6 \mathrm{~N} \mathrm{HCl}$, a small amount of fluoride was found.

\section{Discussion}

The development of an acquired pellicle on the surface of the enamel might be influenced qualitatively by saliva and crevicular fluid. Previous studies have shown that IgG and albumin contribute a part of the total protein in the pellicle on the hydroxyapatite $^{2,8)}$. The pellicle seems to have an important function in prevention of caries ${ }^{9}$. Moreno et al. showed that the composition of the pellicle may be different in fluoridated and non-fluoridated hydroxyapatite ${ }^{10)}$.

In the present investigation, a major portion of the deposited fluoride in fluoridetreated hydroxyapatite was removed by $\mathrm{KOH}$-treatment. This finding indicates that the major portion of deposited fluoride was in the form of calcium fluoride or other labile fluoride and that only small amounts 
of fluoroapatite were formed.

Bernardi et al. have suggested that the adsorption of protein on hydroxyapatite depended on the interaction between negatively charged groups and calcium sites of the apatite surface ${ }^{11)}$. Our experiments showed that the treatment of fluoride interfered with adsorption of an acidic protein, albumin. It seems likely that the formation of calcium fluoride, which gives a decreased number of calcium sites, prevented the adsorption of albumin.

In contrast, the treatment of hydroxyapatite with fluoride slightly increased the adsorption of a cationic protein, IgG. Scully et al. suggested that IgG might be capable of opsonizing Strep. mutans and thereby prevent caries $^{3)}$.

The present study indicates that treatment of fluoride on the enamel surface may affect the composition of the acquired pellicle.

\section{References}

1) Roitt, I. M. and Lehner, T.: Immunology of Oral Disease, p. 363-378, Blackwell, Oxford, 1980.

2) Rölla, G., Clardi, J. and Bowen, W. H.: Identification of IgA, IgG, lysozyme, albumin, $\alpha$-amylase and glucosyltransferase in the protein layer adsorbed to hydroxyapatite from whole saliva. Scand. J. Dent. Res. 91: 186190, 1983.

3) Scully, C. M. and Lehner, T.: Bacterial and strain specificities in opsonization, phagocytosis and killing of Streptococcus mutans.
Clin. Exp. Immunol. 35: 128, 1979.

4) Eggen, K. H. and Rölla, G.: Surface properties of fluoride treated hydroxyapatite as judged by interactions with albumin and lysozyme. Scand. J. Dent. Res. 91: 347-350, 1983.

5) Rölla, G., Hsu, S. D. and Bowen, W. H.: The influence of fluoride on the uptake of protein by hydroxyapatite. Caries Res. 11: 308-312, 1977.

6) Bradford, M. M.: A rapid and sensitive method for the quantitation of microgram quantities of protein utilizing the principle of protein-dye binding. Anal. Biochem. 72: 248-254, 1976.

7) Caslavska, V., Moreno, E. C. and Brudevold, F.: Determination of the calcium fluoride formed from in vitro exposure of human enamel to fluoride solutions. Archs. Oral Biol. 20: 333-339, 1975.

8) Orstavik, D. and Kraus, F. W.: The acquired pellicle: Immunofluorescent demonstration of specific proteins. J. Oral Path. 2: 68-76, 1973.

9) Darling, A.: Studies of the early lesion of enamel caries with transmitted light, polarised light and radiography. Br. Dent. J. 101: 329_ $341,1956$.

10) Moreno, E. C., Kresak, M. and Hay, D. I.: Adsorption of two human parotid salivary macromolecules on hydroxy-, fluorhydroxyand fluorapatite. Archs. Oral Biol. 23: 525533, 1978.

11) Bernardi, G. and Kawasaki, T.: Chromatography of polypeptides and proteins on hydroxyapatite columns. Biochim. Biophys. Acta 160: 301-310, 1968. 